\title{
HIDDEN MEN: BEARING WITNESS TO MANDATORY DETENTION IN AUSTRALIA
}

\author{
Caroline Fleay $^{*}$ and Linda Briskman ${ }^{* *}$
}

\begin{abstract}
The Australian government policy of mandatory immigration detention has been the subject of critique by human rights bodies and civil society. With many immigration detention facilities being located in remote sites, distance and expense means that few people get to observe detention practices in Australia directly. Through direct observations and through the voices of three men detained in the Curtin Immigration Detention Centre outside of the remote Western Australian town of Derby, the human costs of mandatory detention are presented and discussed. This is done through positioning this discussion as part of the process of bearing witness to mandatory detention in Australia.
\end{abstract}

Keywords: mandatory detention, bearing witness, asylum seekers, Australia

\section{Introduction}

Ali $^{1}$ is a Hazara man from Afghanistan. He arrived to Australia by boat in April 2010 and spent eighteen months in immigration detention waiting for the outcome of his refugee claim. Most of this time he was detained in the Curtin Immigration Detention Centre (IDC) located in the remote northwest region of Australia. We got to know Ali well during our visits to Curtin IDC throughout 2011.

Ali fled the terror of Afghanistan under the Taliban. This was not the first time he had attempted to flee for his life. On an earlier journey to Australia in 2001, his boat caught fire and he had to face the fear of jumping into the ocean without being able to swim. After seventeen months of subsequent detention on Nauru, at the behest of the Australian Government's 'Pacific Solution', he was told by Australian officials that it was now safe for him to return to Afghanistan. Ali did return but the ongoing danger there resulted in him fleeing to a precarious life for the next six years in Pakistan and Iran. He then made a second

\footnotetext{
${ }^{*}$ Dr Caroline Fleay is a lecturer at the Centre for Human Rights Education at Curtin University.

** Professor Linda Briskman is Professor of Human Rights at the Swinburne Institute for Social Research.

${ }^{1}$ A pseudonym has been used to maintain his anonymity.
} 
quest for asylum in Australia in 2009 and finally received a permanent visa in September 2011.

After his release from Curtin IDC, Ali recounted his ordeal of trying to find a safe haven. Despite more than a decade of fear, uncertainty and grief, what was striking to us was that it was only when he spoke of his time in the detention centres of Australia that his emotions became uncontrollable and tears welled in his eyes. What became clear was that the experience of Australian detention had been overwhelming in the despair that it had generated for Ali. This reflected the indefinite nature of the detention, the complexities and inconsistencies of the refugee processing system, the rejections Ali received before his claim was finally accepted, the added period of waiting for security clearances, and his dependence on anti-depressant medication to endure the period he was detained. Compounding the detention factors was his desperate worry for his family, a wife and two children, separated by distance in Pakistan while awaiting a decision about Ali's future with which theirs was bound.

Ali's story is illustrative of the experiences of so many people who have been detained in Australian detention centres. This paper explores the narratives of three men who were detained at Curtin IDC to give voice to those subject to Australia's mandatory detention policy under the Australian Labor Government. Upon their release, all three told us they finally felt free to share their experiences and wanted us to tell others. The voices of the Hidden Men of Curtin IDC are rarely heard - the isolation and difficulties of visiting the detention centre mean that few get to talk with them. This paper also draws upon our observations during five visits to the IDC, written material given to us by forty men during one our visits, and information drawn from contact by telephone and email. Because we had been regular visitors, trust was established which resulted in open communication about the trauma experienced in detention. The Hidden Men want their stories told.

This paper is part of the process of bearing witness to mandatory detention in Australia. We begin by exploring what it means to bear witness, and this is followed by an overview of the mandatory detention policy in Australia. The experiences of the Hidden Men are then highlighted to give voice to those who have suffered under the mandatory detention policy.

\section{Bearing witness}

Although formal research within immigration detention facilities is prohibited by the Government, our ethnography within Curtin IDC arises from the belief that it is in the 
interests of people detained to expose the malevolence of the system, in accordance with their wishes. Following Kirmayer, Rousseau and Crepeau's observations on researching the detention of asylum-seekers, we see our efforts as research that is committed to exposing abuses perpetrated by the State. ${ }^{2}$ Consistent with an understanding of social research that gives rise to "an obligation to assist in redressing social problems, wherever possible", 3 research that involves witnessing abuse is accompanied with a responsibility to take action. ${ }^{4}$

Bearing witness involves 'attending closely and openly' to the expressions of the experiences of another, and then communicating this to others. ${ }^{5}$ The impact of this on someone experiencing great suffering can be a sense that they are not alone. But this attendance is also a starting point for action:

Witnessing has both personal and political consequences for those who are unable to enjoy human rights. Firstly, it reassures such persons that they have not been abandoned. Secondly, witnessing acts as testimony from which action can begin. ${ }^{6}$

We argue that this second consequence is imperative in bearing witness. To witness an abuse means to become responsible for taking some form of action in response, ${ }^{7}$ including attempts to broaden the sphere of felt responsibility. ${ }^{8}$ Kurasawa likens such a process to placing messages in bottles and throwing them in the sea with the aim of persuading those who find the bottles to take action:

Bearing witness requires that addressees pick up the bottles washed up on land, decipher the enclosed messages, ponder them and intervene accordingly with the aim of alerting the world, making sense of what has taken place, cultivating empathy, remembering and preventing the

\footnotetext{
${ }^{2}$ L.J. Kirmayer, C. Rousseau \& F. Crepeau, "Research Ethics and the Plight of Refugees in Detention' Monash Bioethics Review, 23(4), 2004, 86.

${ }^{3}$ C. Mackenzie, C. McDowell \& E. Pittaway, "Beyond 'do no harm': the Challenge of Constructing Ethical Relationships in Refugee Research”, Journal of Refugee Studies 20(2) 2007, 310.

${ }^{4}$ R. Hugman, E. Pittaway, \& L. Bartolomei, "When 'Do No Harm' is Not Enough: The Ethics of Research with Refugees and Other Vulnerable Groups", British Journal of Social Work 41, 2011, 1272.

${ }^{5}$ W.K. Cody, "The Ethics of Bearing Witness in Healthcare: A Beginning Exploration", Nursing Science Quarterly, 14(4), 2001, 289.

${ }^{6}$ D. Zion, L. Briskman and B. Loff, "Psychiatric Ethics and a Politics of Compassion: The Case of Detained Asylum Seekers in Australia", Bioethical Inquiry, 9, 2012, 73.

${ }^{7}$ J.D. Peters, "Witnessing”, Media, Culture and Society, 23, 2001, 708.

${ }^{8}$ S. Tait, "Bearing Witness, Journalism and Moral Responsibility", Media, Culture and Society, 33(8), 2011, 1227.
} 
reoccurrence of the immediate or structural circumstances that are at the root of mass suffering. ${ }^{9}$

Thus bearing witness involves communicating what has been seen and heard in ways that encourage the receivers of the message to take action in response.

However, as with all instances of communication, issues of selectivity and portrayal need to be interrogated. There is a selection process when portraying what it is we think we have witnessed, whether conscious or not. In the communication component of witnessing, we can put into words what we have witnessed but we cannot transmit the experiences themselves. We become an active witness, one who is a "privileged possessor and producer of knowledge". ${ }^{10}$ Inevitably, choosing to bear witness in a certain way and in a particular place also means that a choice has been made to not bear witness in a different way or place. ${ }^{11}$ This raises questions about whose experiences are elevated in our choices of bearing witness and whose remain hidden.

Issues of power need acknowledging. Rather than being detached "objective" observers we are involved in the lives of the participants. Relationships of friendship develop when detention centres are repeatedly visited, allowing the gaining of insight into the lived experiences of asylum-seekers that may not otherwise be possible in such a researcherparticipant encounter. But such a relationship is not immune to issues of power. There is a need to be aware of our identity as "white, western researchers [...] and the impact that this has on the research relationship". ${ }^{12}$ Our membership of the dominant white community in Australia and university employment provides us with social standing in the eyes of many detained and affords us a respect, however deserving this may or may not be. As long-term advocates of asylum-seekers in Australia, we have also developed a sound understanding of the immigration system, a system unfathomable to many detained. In 2011 we were among the few visitors to Curtin IDC, increasing the reliance that many asylum-seekers had on us to bear witness to their detention and to take action in response. All of these factors contributed

\footnotetext{
${ }^{9}$ F. Kurasawa, “A Message in a Bottle: Bearing Witness as a Mode of Transnational Practice”, Theory, Culture and Society, 26, 2009, 97.

10 J.D. Peters, Witnessing, 709 (original emphasis).

${ }^{11}$ W.K. Cody, "The Ethics", 290.

${ }^{12}$ R. Hugman, E. Pittaway, \& L. Bartolomei, "When 'Do No Harm””, 1283-1284.
} 
to an inevitable imbalance of power between us as advocates/researchers and asylum-seekers in detention.

However, there is a much greater imbalance of power between detainees and those ultimately responsible for their detention - the Australian Government - and those responsible for allowing their detention to be maintained - the Department of Immigration and Citizenship (DIAC), employees of the private detention provider organization (Serco) and the healthcare contractors who work at Curtin IDC. We argue that the ethical implications of conducting research into the detention of asylum-seekers outlined above, while important to consider, should not discourage ethnography of this kind. Bearing witness to detention in Australia is still the domain of the relatively few and telling the stories is a way of providing increased transparency and overcoming the prevailing secrecy.

Our major justification is that the monitoring mechanisms in place in Australia to provide independent oversight of the immigration detention system are extremely limited. To some extent, this is because Australia has signed but not yet ratified the Optional Protocol to the Convention against Torture (OPCAT), which would provide a mandate for a more comprehensive inspection process of immigration detention facilities. Some monitoring is provided by statutory bodies such as the Australian Human Rights Commission and Commonwealth Ombudsman, and there have been a number of official inquiries into detention, the most recent being the 2012 Joint Select Committee on Australia's Immigration Detention Network. In addition, there is the Ministerial Council on Asylum-Seekers and Detention that provides confidential advice to the Minister for Immigration. Non-government organizations such as Amnesty International and the Australian Red Cross also visit immigration detention centres. Although all of these bodies play an important role and produce significant reports, they do not have the power to enforce their recommendations. Even when the findings of the statutory bodies are presented to Parliament, we have observed that little is done to ensure their recommendations influence policies and practices. Even when policies and practices do change, unchallenged legislation does not ensure their longevity.

Some reports have been undertaken on Curtin IDC explicitly, including by the Australian Human Rights Commission and Amnesty International, and their findings have presented deep concerns about the facility. ${ }^{13}$ Although these more formal reports are

\footnotetext{
${ }^{13}$ Australia Human Rights Commission (AHRC), "Immigration Detention at Curtin: Observations from Visit to Curtin Immigration Detention Centre and Key Concerns across the Detention Network 2011", available at:
} 
welcome, anecdotal information from detainees indicates that when formal monitoring or reporting organizations visit asylum-seeker detention, their visits usually only last a matter of hours, are controlled by DIAC and Serco officials and somewhat orchestrated (including reports that places of detention are subject to hasty improvements just prior to visits), and very few detainees are provided with an opportunity to air their opinions. ${ }^{14}$ The opportunity for media coverage is also limited, with few journalists gaining permission to enter detention facilities to speak with asylum-seekers.

The limitations of the current monitoring of Australia's immigration detention centres and the limits of reporting on what has occurred require that others need to bear witness. There are a number of civil society organizations that work tirelessly advocating for the end of immigration detention and produce information on the problematic practices within the facilities. Although such groups focus by and large on the national single issue of ending mandatory immigration detention, as we indeed do, there are a multiplicity of approaches for these endeavours and these are to be applauded. Such movements represent alternative visions of democracy ${ }^{15}$ and although the concept of a social movement is premised on collective action, there is space within the broad collectivity for actions that move beyond existing methods such as protest events and lobbying politicians. Our contribution to creating an alternative vision is that by bearing witness through visits and direct and regular contact with detainees we endeavour to encourage others to move beyond that of outraged bystander to that of activist ethnographer.

\section{Mandatory detention from Howard to Gillard}

Mandatory detention was first enshrined in Australian law by the Keating Labor Government in 1992. The policy requires that all asylum-seekers who arrive undocumented, usually by boat, to Australia seeking refugee status be detained until their claim has been finalised. Asylum-seekers arriving by air are generally not detained for the duration of the processing

http://www.hreoc.gov.au/human_rights/immigration/idc2011_curtin.html (last visited 30 March 2012); See also: Amnesty International Australia (AIA), "Detention Facilities Visit 2012”, Media Briefing, 22 Feb. 2012.

${ }^{14}$ We saw and heard evidence of this during our May 2011 visit to Curtin IDC. We noticed increased numbers of plants and notices of activities throughout the centre as compared with our previous visit four months prior, and were told by detainees that these had appeared just before the visit by the Australian Human Rights Commission that month.

${ }^{15}$ D. della Porta, (2009), "Democracy in Movements: Some Conclusions" in Democracy in Social Movements, D. della Porta (ed.), New York, Palgrave Macmillan, 2009. 
of their claim. Thus the policy effectively discriminates between asylum-seekers arriving by boat and those who seek asylum once they are already in Australia or who arrive by plane. ${ }^{16}$

The policy was expanded under the Howard Coalition Government from 1996 to 2007. Most notably the Howard Government excised the Australian islands surrounding the mainland for immigration purposes, so that asylum-seekers arriving at those islands could not access Australia's refugee protection system; and this dual policy system remained in place until 2012. New detention centres, privately operated, were established in remote locations within Australia, including Curtin IDC, and offshore on Nauru and Papua New Guinea's Manus Island. Many asylum-seekers were detained for years under the Howard Government's policies, with the explicit government aim of deterring others. ${ }^{17}$

Growing opposition from domestic and international human rights organizations, refugee advocates, and Members of Parliament within the Howard Government itself, meant that by 2006 there was some softening of the detention policy. In particular, a group of Government backbenchers had forced their Prime Minister to negotiate over the treatment of asylum-seekers and helped to bring about the release of women and children and most longterm detainees from detention. ${ }^{18}$ The Australian Labor Party (ALP) supported this opposition and prior to the 2007 election called for improvements in asylum-seeker policies. In particular, the ALP argued that:

[d]etention of asylum-seekers should only be used for health, identity and security checks. Children and family groups should initially be placed under supervision within the community $[\ldots]$ [and the] length and conditions of detention must be subject to review. ${ }^{19}$

Soon after its election in November 2007 the Labor Government, under the leadership of Kevin Rudd, closed the immigration detention centres on Nauru and Manus Island. ${ }^{20}$ Immigration Minister Chris Evans announced the new Government's Key Immigration

\footnotetext{
${ }^{16}$ N. Viviani, The Indochinese in Australia 1975-1995: From Burnt Boats to Barbecues. Oxford: Oxford University Press, 1996, 20-21.

${ }^{17}$ L. Briskman, S. Latham \& C. Goddard, Human Rights Overboard: Seeking Asylum in Australia. Carlton North, Victoria, Scribe, 2008, 112.

${ }^{18}$ C. Fleay, Australia and Human Rights: Situating the Howard Government. Cambridge Scholar Publishing, Newcastle-Upon-Tyne, 2010, 121-126.

19 Australian Labor Party (ALP), National Platform and Constitution 2007, available at: www.nit.com.au/downloads/files/Download_161.pdf (last visited 16 May 2011).

${ }^{20}$ Briskman, Latham \& Goddard, Human Rights, 386.
} 
Detention Values, including that "detention in Immigration Detention Centres [would only] be used as a last resort and for the shortest practicable time" and children would not be placed in a detention centre. ${ }^{21}$

However, as boat arrivals of asylum-seekers began to increase once more, the Labor Government, first under the leadership of Kevin Rudd and then Julia Gillard from June 2010, responded by reinforcing the indefinite nature of the mandatory detention policy and expanding the immigration detention network. This included the re-opening of Curtin IDC in June 2010. Adding to the length of time thousands of asylum-seekers would spend in detention was the Rudd Government's decision in April 2010 to suspend the processing of refugee claims for Sri Lankan and Afghan asylum-seekers for three and six months consecutively. This suggested that the Government anticipated these asylum-seekers could soon return to their own countries without fear of persecution. ${ }^{22}$ Processing resumed at the end of these time periods but, reflecting the suspension and the backlog of claims processing that it generated, many months were added to the time spent in detention for these asylumseekers including many detained at Curtin IDC.

As concerns grew for the welfare of asylum-seekers spending many months in detention, the Gillard Government announced in October 2010 that the majority of families and children would be released from immigration detention facilities by the following June. A bare majority had been released by this deadline ${ }^{23}$ and it took further months for other families and children to be released from detention facilities. As at the end of May 2012 there were 516 children in forms of immigration detention, with DIAC claims that the majority had been there "for less than two months". ${ }^{24}$

In addition to the growing concerns being expressed by monitoring bodies and refugee advocates regarding the effects of long-term detention, protests within immigration detention centres increased in 2011 as expanding numbers of men remained there for months

\footnotetext{
${ }^{21}$ C. Evans, "New Directions in Detention, Restoring Integrity to Australia's Immigration System" Seminar Centre for International and Public Law, Australian National University, 29 Jul. 2008, 7-8.

${ }^{22}$ C. Evans, "Suspension on Processing of all New Applications from Asylum-seekers from Sri Lanka and Afghanistan" 9 April 2010, available at: www.minister.immi.gov.au/media/speeches/2010/ce100409.htm (last visited 5 May 2011).

${ }^{23}$ Australian Broadcasting Corporation (ABC) PM, Minister Reports on Children in Detention, 29 June 2011, available at: www.abc.net.au/pm/content/2011/s3256762.htm (last visited 8 Dec. 2011).

${ }^{24}$ Department of Immigration and Citizenship (DIAC), Immigration Detention Statistics Summary 31 May 2012, 7 available at: http://www.immi.gov.au/managing-australias-borders/detention/facilities/statistics/ (last visited 25 June 2012).
} 
on end. In November 2011 the Government responded ${ }^{25}$ by announcing that long-term detainees considered to pose no risks to the community would be allowed to reside outside of a detention centre while their refugee claim was being finalised, either through the community detention program or on a bridging visa. ${ }^{26}$ Despite relatively few men being released under these programs over the following months, by 21 May 2012 1,780 had been issued with bridging visas. A further 465 men had been placed in community detention. ${ }^{27}$ However, concerns remained at this time for 1,434 people who had been detained for more than one year, including 433 for more than two years. ${ }^{28}$ There is also disquiet about the limited support given to former detainees once they are issued with a bridging visa, such as the difficulties involved in asylum-seekers on temporary visas trying to gain employment. ${ }^{29}$

\section{Despair at Curtin}

Curtin IDC in remote northwest Australia was first opened in September 1999 by the Howard Government. It is situated in the Curtin Royal Australian Air Force base, 2,300 kilometres north of the capital city of Perth. The detention centre was closed in September 2002, three years after its first opening, following growing unrest within the centre and declining boat arrivals to Australia. The centre was re-opened in June 2010 to hold adult male asylumseekers and by early 2011 it was detaining the largest number of asylum-seekers in Australia. Operated by Serco, it is a high security centre that is surrounded by two large fences that are electrified.

\footnotetext{
${ }^{25}$ C. Bowen, "Bridging Visas to be Issued for Boat Arrivals" Minister for Immigration and Citizenship, Media Release, 25 Nov. 2011, available at: www.minister.immi.gov.au/media/cb/2011/cb180599.htm (last visited 8 Dec. 2011).

${ }^{26}$ Under the Migration Act (Cth), the Minister for Immigration and Citizenship can allow people in immigration detention to be released into community detention, that is, to live at a specified address outside of a detention centre without the need to be escorted. Community detention thus allows for the release of vulnerable detainees from detention centres before their refugee claim has been finalised, although it is exercised at the Minister's discretion. For those detainees considered to be capable of employment, a bridging visa including the right to seek employment can be issued. (See E. Koleth, Asylum-Seekers: An Update, Briefing Paper No 1/2012, NSW Parliamentary Library Research Service, 2012, 40-43).

${ }^{27}$ Commonwealth of Australia, Proof Committee Hansard, Senate, Legal and Constitutional Affairs Legislation Committee Estimates, Monday 21 May 2012, 75, 117, Canberra, available at: http://parlinfo.aph.gov.au/parlInfo/search/display/display.w3p;query=Id\%3A\%22committees/estimate/b429b5 c1-1858-47f9-ab41-542ef70c9e51/0000\%22 (last visited 30 May 2012).

${ }^{28}$ DIAC, Immigration Detention Statistics Summary, 8.

${ }^{29}$ These concerns were communicated to the authors during conversations with eight former Curtin IDC detainees in Perth and Sydney, Mar. 2012.
} 


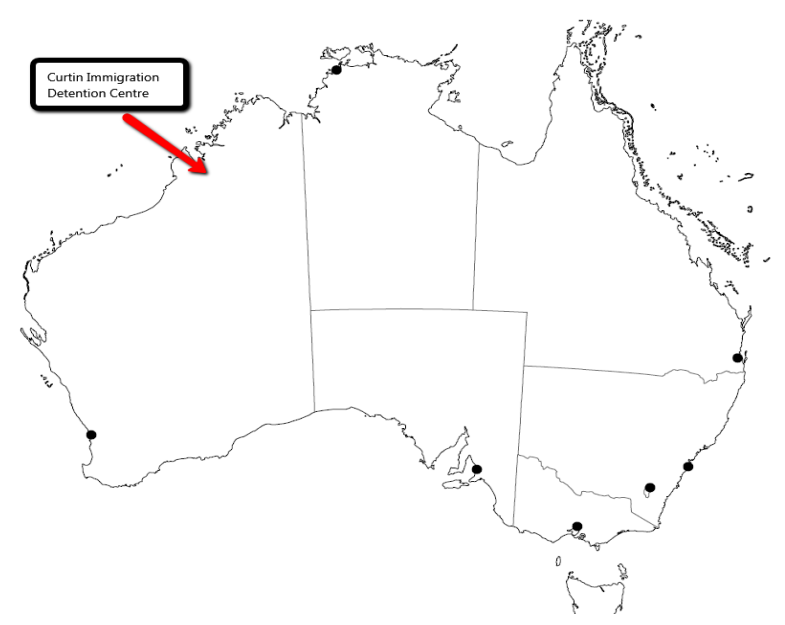

\section{Figure 1. Location of Curtin Immigration Detention Centre.}

(C) Commonwealth of Australia (Geoscience Australia) 2010

The re-opening of Curtin IDC was cause for alarm for those who had formerly been detained there and refugee advocates. ${ }^{30}$ Research and reports had documented the despair and illtreatment of asylum-seekers in remote detention centres, including Curtin IDC during its first three years of operation. ${ }^{31}$ Recent reports illustrate that long periods of detention in such a remote location generates despair. ${ }^{32}$ While there have been some improvements in

${ }^{30}$ Sydney Morning Herald (SMH), "Hope Turns to Dust in the Middle of Nowhere", 3 May 2010, available at:
www.smh.com.au/national/hope-turns-to-dust-in-the-middle-of-nowhere-20100502-u1ja.html (last visited 10
May 2011).
${ }^{31}$ For example, see Justice P.N. Bhagwati, "Human Rights and Immigration Detention in Australia". Report of
Justice P.N. Bhagwati, Regional Advisor for Asia and the Pacific of the UN High Commissioner for Human
Rights, Mission to Australia $\quad 24 \quad$ May-2 Jun. 2002, available at: http://motspluriels.arts.uwa.edu.au/BhagwatiReport.pdf (last visited 20 Oct. 2008); Briskman, Latham \& Goddard, Human Rights (2008); Human Rights and Equal Opportunity Commission. "A Last Resort? National Inquiry into Children in Immigration Detention.” 2004. http://www.hreoc.gov.au/human_rights/children_detention_report/index.html (last visited 14 Oct. 2008); Joint Standing Committee on Foreign Affairs, Defence and Trade. "Completed Inquiry: Visits to Immigration Detention Centres." 18 Jun. 2001. http://www.aph.gov.au/House/ committee/jfadt/IDCVisits/IDCindex.htm (last visited 20 Oct. 2008); Joint Standing Committee on Foreign Affairs, Defence and Trade. "Statement to the Parliament on the Joint Standing Committee on Foreign Affairs, Defence and Trade Human Rights SubCommittee's Recent Activities Concerning Conditions within Immigration Detention Centres and the Treatment of Detainees." 13 Oct. 2003. http://www.aph.gov.au/House/committee/ jfadt/detention_statement/statement.pdf (last visited 20 Oct. 2008); Z. Steel, S. Momartin, C. Bateman, A. Hafshejani, D. M. Silove, N. Everson, K. Roy, M. Dudley, L. Newman, B. Blick \& S. Mares. "Psychiatric Status of Asylum-Seeker Families held for a Protracted Period in a Remote Detention Centre in Australia." Australian and New Zealand Journal of Public Health 28 (6), 2004, 527-536; and United Nations Working Group on Arbitrary Detention. "Report of the Working Group on Arbitrary Detention: Visit to Australia." 24 Oct. 2002, available at: http://daccessdds.un.org/doc/UNDOC/GEN/G02/153/91/ PDF/G0215391.pdf?OpenElement (last visited 13 Oct. 2008).

${ }^{32}$ See Australia Human Rights Commission "Immigration Detention at Curtin: Observations from Visit to Curtin Immigration Detention Centre and Key Concerns across the Detention Network 2011", available at: 
infrastructure at Curtin IDC in 2011 compared with its facilities in 2002, the indefinite nature of detention continues to be the overwhelming cause of despair, compounded by its remoteness. As one of the detainees in 2011 who had also been detained in the centre during its first period told us, "90 per cent is the same".

Even Australia's Minister for Immigration, Chris Bowen, acknowledged on Australian television in late 2011 his concerns regarding detaining asylum-seekers at Curtin IDC:

We need to reduce the number of people in detention, and obviously I would consider Curtin as a centre to close before I close other centres which are perhaps less confronting and less harsh. I do think Curtin is a harsh environment for that particular group of people. ${ }^{33}$

However, a communication to us from the Minister for Immigration and Citizenship, Chris Bowen, in February 2012 stated that "there are no plans to close Curtin IDC". 34

During our visits to Curtin IDC throughout 2011, we spent many hours talking with hundreds of the men detained there. In addition, we received regular telephone calls and emails from some of those detained throughout the year; some wrote their concerns on paper. Upon their release from detention, three of the detainees agreed to be interviewed in order to document their experiences of detention in Australia - Ali, Dawood Jan Urozgani and Hussain Ramazani. Ali was released from detention with a permanent visa in September 2011 after waiting 18 months in detention for his refugee claim to be finalised. Dawood Jan was released from Curtin IDC into community detention in October 2011 after 18 months in detention. He was found to be a refugee in February 2012. In January 2012 Hussain was released into community detention after 20 months in detention. He was granted refugee

http://www.hreoc.gov.au/human_rights/immigration/idc2011_curtin.html (last visited 30 March 2012); Centre for Human Rights Education, Curtin University, \& Asylum-Seekers Christmas Island, Joint Submission, Joint Select Committee on Australia's Immigration Detention Network, Aug. 2011 available at: http://www.aph.gov.au/Senate/committee/immigration_detention_ctte/immigration_detention/submissions.ht m (last visited 30 November 2011); and C. Fleay \& L. Briskman, "The Hidden Men: A Report to the Minister for Immigration and Citizenship on Visits to the Curtin Immigration Detention Centre", November 2011, available at: http://blogs.curtin.edu.au/human-rights-education/2011/11/22/report-the-hidden-men/ (last visited 27 August 2012).

33 ABC Four Corners, Asylum, 24 October 2011, available at: http://www.abc.net.au/4corners/stories/2011/10/20/3344543.htm (last visited 24 March 2012).

${ }^{34}$ C. Bowen, "New Single Protection Visa Process Set to Commence" Minister for Immigration and Citizenship Media Release, 19 Mar. 2012, available at: www.minister.immi.gov.au/media/cb/2012/cb184344.htm (last visited 26 Jul. 2012). 
status several weeks later. Through our visits to Curtin IDC, the regular contact by telephone and email between visits, and the subsequent interviews with Ali, Dawood Jan and Hussain, we witnessed the impacts that mandatory detention has had on these asylum-seekers.

The experiences of Ali, Dawood Jan and Hussain illustrate the despair that is endured by many asylum-seekers in Australia's immigration detention centres. The ongoing anguish was generated and exacerbated by the lengthy periods of time all three men had been detained without knowing when they may be released, reflecting the mandatory detention policy and the inconsistent processes involved in finalising refugee claims. Their misery was also deepened through the lack of anything meaningful to do to fill in the time while in detention, and the barriers to communication with friends, family and support groups outside detention. Another factor that exacerbated their miserable circumstances was the lack of understanding of some detention centre employees regarding how to handle traumatised asylum-seekers. The depth of the despair experienced by asylum-seekers in Curtin IDC was evident in the deterioration of the mental and physical health of the men that we directly observed during our visits from January to November 2011 and from telephone and email contact. The following areas were those of the greatest concern arising from the interviews, our observations and ongoing contact with detainees. The narratives of the three men interviewed in-depth are indicative of the situation of the detained men.

\section{Flawed claims processing}

As mandatory detention allows for asylum-seekers arriving by boat to be detained until their refugee claims have been finalised, delays in this process can mean lengthy periods in detention. During our first visit to Curtin IDC in January 2011, it was evident that many of the men detained were extremely anxious about their refugee claims that were yet to be assessed. All of the 1,200 detainees at this time were from Afghanistan, with the vast majority being from the Hazara ethnic group. Hazaras in Afghanistan have faced persecution for several centuries. More recently many Hazaras have been internally displaced within Afghanistan and subject to persecution by the Taliban and other local militias. ${ }^{35}$ Many of the men at Curtin IDC in January 2011 had arrived by boat to Australia during the six month period during which the refugee claims of Hazaras had been suspended. Most were still waiting for their claims to be assessed according to the Refugee Status Assessment (RSA)

\footnotetext{
${ }^{35}$ W. Maley, "On the Position of the Hazara Minority in Afghanistan", 7 December 2011, available at: http://bmrsg.org.au/wp-content/.../Maley-Hazaras-Opinion-Updated2.pdf (last visited 29 Mar. 2012).
} 
process by DIAC. Consistently detainees told us in person or in writing about the effect this cruel suspension was having on their well-being and their sense of hope. "We are still here but others who arrived later have gone. Why?" and "Don't destroy my life" were among the responses of detainees to the delays caused by the suspension.

More specifically, within several months of that first visit, all three interviewees had received negative RSA outcomes from DIAC. Their despair at this news was apparent during their regular telephone calls and emails. Upon our second visit to Curtin IDC at the end of May, it was evident that this had begun to take a mental and physical toll on the men. Dawood Jan had physically aged in the four months since the previous visit - his face had become etched with the despair he described he was feeling. Reflecting on the months that he had had to wait for this initial decision, he said he felt he had been "sacrificed to politics".

After receiving the negative RSA decision in March 2011, ten months after arriving to Australia, Dawood Jan had to wait another four months for the Independent Merits Review process of this decision to be commenced. ${ }^{36}$ His anguish throughout this waiting period worsened as the months dragged on. In late July he had an exhausting five hour interview with an independent reviewer. The following three months that Dawood Jan spent in immigration detention were filled with a deepening depression as he waited for news of the outcome of his IMR. During our visit to Curtin IDC in September it was clear that Dawood Jan had become extremely withdrawn and was spending many hours each day alone in his room. He began self-harming later that month and was having suicidal thoughts. He described how he became "so scared about what I might do". After significant support from us and refugee advocates, DIAC finally agreed to place Dawood Jan into community detention in October. In February 2012, more than six months after his IMR interview, he received the news that his reviewer had found him to be a refugee.

Ali had arrived to Australian territory on the day that the processing of refugee claims for Afghans was suspended for six months. He had to wait twelve months before being told that his RSA decision was negative. His mental health soon deteriorated and he too commenced taking anti-depressant medication. Ali had to wait a further two months for his IMR interview.

Additional stress was placed on Ali at the time of his IMR interview, a date that coincided with one of our visits to Curtin IDC. The night before his IMR interview he was

\footnotetext{
${ }^{36}$ Up until Mar. 2012, the refugee claims process for asylum-seekers who arrived by boat allowed for negative Refugee Status Assessment decisions to be reviewed by an independent reviewer according to the Independent Merits Review process. From 24 Mar. 2012 the refugee claims process for boat arrivals became consistent with the claims process for air arrivals (see above footnote 35 ).
} 
told by Serco employees that he would be flown to Brisbane the following day. No reason was given for this, even when Ali protested that his IMR interview was scheduled for the next day. "I didn't know why until I got to Brisbane", when he was told that he was required to attend a court hearing for a people smuggling case. After complaints to DIAC from both ourselves and the IMR reviewer, an IMR interview was organised for Ali in Brisbane later that week. During that week, however, Ali experienced considerable distress at not knowing what was going to happen in relation to his IMR. He was not officially told of the new interview date until he had been in Brisbane for four days. Nor was he allowed to make phone calls to his friends to alert them to where he was. Through ringing the immigration detention centre in Brisbane we were able to find out where he was being held and managed to talk to him at the end of his second day in Brisbane. However, every time he received a phone call from us there was a Serco employee in his room so a private conversation was impossible. It was not until later that week that Ali was finally allowed to call his family to let them know why he had not been able to call them as planned that week. Upon being returned to Curtin IDC the day after his IMR interview, Ali said that he had been so relieved to be back in the detention centre as he finally had "no Serco in my room".

After waiting another two months in detention at Curtin IDC, Ali received the news that his IMR reviewer had overturned his initial negative RSA decision. He had been recognized as a refugee. But he had to wait in detention a further two months for a security clearance to be approved by ASIO, the final part of the refugee claims process before Ali could be released from detention.

Hussain arrived to Australian territory in June 2010. It was nine months before he received his negative RSA decision, and he waited another seven months before his IMR interview was scheduled. As with Ali, Hussain was subjected to additional stress in relation to this scheduled interview. On the day of the interview in October 2011, after having been in detention for sixteen months, he was told that it was cancelled. Hussain did not understand the reason for the cancellation and one week later he was transferred to Pontville IDC in Tasmania. He described that "his feeling had been very bad" at this time and that he had become so "tired of talking about his case" to immigration officials. It was not until a further week had passed that we were able to find out from his migration agent that his IMR had been cancelled because his reviewer had run out of time to conduct his interview, and we communicated this with Hussain. A further interview was organised for him the following month, however, it was scheduled to occur at Curtin IDC. We alerted Hussain's migration agent to the fact that he was now in Pontville and this interview was also cancelled. It was not 
until early December that Hussain finally had his IMR interview at Pontville IDC. After two more months of waiting, he received the news that he was to be recognized as a refugee. By the time that Hussain was released from detention, after twenty months, his mental and physical health had significantly deteriorated. He was suffering from serious kidney and back problems as well as feelings of constant despair and suicidal thoughts.

As with many of the detainees at the Curtin IDC, the lengths of time Ali, Dawood Jan and Hussain had to endure in detention reflected the inconsistency of the refugee assessment process as well as the six month suspension period from April to October 2010. Reports from the three interviewees, and many other men we spoke with in Curtin, suggest that some migration agents are conscientious and prepare extensive submissions for their clients at both the RSA and IMR stage while others do not. Reports from many men detained at Curtin suggest that there have been inconsistencies between DIAC officials and IMR reviewers concerning their findings on refugee claims. There have also been reports of inconsistencies in the reliability and quality of interpreting services. For example, given his good understanding of English, several times during Dawood Jan's IMR interview he interrupted his interpreter in order to more accurately convey his situation to the reviewer. Hussain reported that the interpreter assisting him with his initial statement to DIAC had made a translation mistake and that this may have contributed to his negative RSA decision. Additional time in detention for asylum-seekers such as Ali and Hussain was created through organizational errors in the claims process. Their examples highlight the significant impacts such errors have on the wellbeing of asylum-seekers in detention.

\section{Boredom and barriers to communication}

Daily life in detention is filled with boredom that feeds despair. As Dawood Jan described it, life in Curtin IDC came to feel interminable, "one day in the detention centre is the same as one year outside". With little to do to fill the time, the men worried about their refugee claims, their physical and mental health, their friends in detention, and their families who were all living in precarious or dangerous situations. All of the men interviewed suffered from physical ailments as well as mental health issues. Like many of the other men in Curtin IDC, all had visited a counsellor or psychologist during their many months in detention, and Ali and Dawood Jan had been prescribed medication for depression. The three men had also been taking medication for physical health problems.

During our visits to Curtin IDC we noticed that during the heat of the day many of the men remained in their rooms. Those who were outside and in our view were often listless and 
seemed barely aware of their surroundings. In the late afternoon when the sun was less oppressive we saw men walking around and around, going nowhere, but trying to relieve the boredom of the day. This pattern seemed to be repeated day after day. One detainee told us that he was made to feel less than human and caged. Another talked about being "kept away from normal people and dying every moment".

Further exacerbating experiences of despair during their time in detention were the great difficulties in communicating with friends, family and migration agents outside of Curtin IDC. The remoteness of the detention centre means that it is expensive and timeconsuming to visit any of the detainees. For most visitors, except for the few Derby residents who travel the 50 kilometres by car to visit, the cost alone is prohibitive. When we visited from Perth, we had to fly for 2.5 hours to Broome then hire a car and drive a further two hours to the detention centre. Given accommodation costs in Derby have also escalated due to the detention centre, this is an extremely expensive place to visit.

Internet access at Curtin IDC is vastly inadequate for the 1,000-1,500 men that it has detained at any one time. There are eighteen computers at the detention centre and the detainees must start queuing at 5am in the morning to try to book one of the computers for one hour that day. The internet access organised for the detention centre is also often slow and sometimes does not work. This makes it very hard for detainees to use the internet to keep in touch with friends and family and to find out news of home.

All detainees can access telephones to call outside the detention centre if they purchase a phone card. Many of the phones are situated outside under a verandah roof and at certain times of the day are in the direct sunlight. This limits the times that it is bearable for detainees to make calls. Certain times of the year the mosquitoes at Curtin IDC are voracious, particularly in the evenings, which further limits the times that the men can make telephone calls. The phones do not receive incoming calls and thus it is very difficult to try to contact any of the men by phone. This includes migration agents who have to arrange with Serco a time to call their clients and this has often taken up to five days. For example, Dawood Jan's migration agent needed to talk with him urgently several weeks after his IMR interview but was unable to do so for five days.

\section{(Mis)handling of traumatised asylum-seekers}

One prominent theme from the interviews with Ali, Dawood Jan and Hussain, our observations during the visits to Curtin IDC, and the written accounts of detention provided to us, was that there was a clear lack of understanding and expertise by some detention centre 
employees in how to handle traumatised asylum-seekers. This included placing detainees in situations where their despair would be magnified by being in the position of witnessing the trauma of others. All three commented on how difficult it was to see the despair of others in detention, particularly close friends. Just weeks before receiving his negative RSA outcome, Dawood Jan saw another detainee's attempted suicide. Dawood Jan had been walking past a room where a man was hanging from the ceiling with a sheet around his neck. He saw that a Serco employee who had found the man was not able to hold him up in order to prevent him from dying. Dawood Jan assisted by holding the man until he could be cut down, saving his life. This experience immediately had an impact on Dawood Jan's own mental health, resulting in regular nightmares, sleeplessness, depression and anxiety over the many months he remained in detention to follow. He also experienced physical symptoms such as stomach ailments and commenced taking anti-depressant medication after this incident. The impact of this incident on Dawood Jan was further magnified when he was woken in the middle of one night in July by a Serco employee and told to accompany him to the medical compound. Alarmed at this request, Dawood Jan questioned the request and told the Serco employee "but I am not sick". No reason was given and Dawood Jan felt he had to go to the medical compound. When he arrived, he could see that another detainee had tried to commit suicide. Dawood Jan had been brought to the medical compound to help interpret the communications between Serco employees and the clearly distressed detainee. The following day Dawood Jan was not able to leave his room, such was the trauma that this generated in him, and once again his own despair was exacerbated.

The importance of visitors to detainees was also not well understood by some Serco employees. Ali, Dawood Jan and Hussain all said how important that visits from people outside of the immigration system were to them. Visitors provided hope that they were not alone in the detention system and that there was emotional and practical help available to them from outside the detention centre. Given the remoteness of Curtin IDC, there were few such visitors. One of the very few weekly visitors to Curtin IDC attempted to meet regularly with both Dawood Jan and Hussain. On several occasions, however, she was told neither of the men could be found for the visit. During one of our visits to the detention centre, we were with Dawood Jan and Hussain as they saw this visitor being escorted out of Curtin IDC. This was after both men had asked Serco employees at the entrance to the main compound if she had arrived as they were waiting for her visit. They found out later that their visitor had been told neither of the men could be found. Their distress at missing out on this visit was clearly visible. 
The way we were treated when visiting also caused some embarrassment for our friends. For example, although we had brought food to share, during some visits we were required to leave the visiting area at lunch-time and sit some metres away at the reception area. Coming from societies where hospitality is the norm, the detainees were clearly aggrieved by the absurdity of this rule and being placed in a position of guarding the food for an hour until we were able to return. Detainees spoke of the inconsistency of their treatment by staff, with DIAC and Serco employees being described as "some aggressive, some kind", and some whose behaviour was described as "treating bad". There was constant criticism of DIAC case managers who were generally seen as unhelpful, lacking knowledge that would be helpful to detainees, and "not treating us equally". We too experienced inconsistencies with staff, some of whom were clearly fond of the men and went beyond the call of duty to be considerate. Others were hostile and displayed attitudes that revealed no understanding of cultural issues or how traumatised the detainees were. One even told us that it was preferable to work in prisons as the prisoners had better manners than immigration detainees.

There was one specific incident that pointed to the lack of duty of care within detention. A note was delivered to us during one of our visits that had been written by a detainee threatening suicide. We tried in many ways to alert authorities to this situation to no avail. When by stealth we finally found a mobile phone number belonging to the health provider organization, the concern relayed was about the fact that we had this number, rather than the fact of the suicide threat.

\section{Discussion}

The experiences of Ali, Dawood Jan and Hussain outlined above illustrate the feelings of despair that is generated by lengthy periods of detention in Curtin IDC. Under Australia's mandatory detention policy, none of the men, nor any of the other detainees in Australia's immigration detention centres, knew how long they would be in detention. For most of the time that Ali, Dawood Jan and Hussain were in detention, DIAC policy was to detain all asylum-seekers who arrived by boat until their refugee claims were finalised. Given the inconsistencies of the claims processes, and the adoption of the claims suspension policy in 2010 , this meant detention periods of eighteen months or more. Witnessing the despair of others, the boredom of detention and barriers to communication with those outside, and the lack of understanding by some detention centre employees about how to handle traumatised asylum-seekers, exacerbated their deep distress. 
Ali, Dawood Jan and Hussain's experiences also contravene some of the Labor Government's own Key Immigration Detention Values, including:

4. Detention that is indefinite or otherwise arbitrary is not acceptable and the length and conditions of detention, including the appropriateness of both the accommodation and the services provided, would be subject to regular review.

5. Detention in immigration detention centres is only to be used as a last resort and for the shortest practicable time.

7. Conditions of detention will ensure the inherent dignity of the human person. ${ }^{37}$

All of the interviewees' experiences of immigration detention illustrate that their detention has been indefinite and for excessive periods of time. Detention was also used as a first rather than last resort, and not subject to regular review. This is clearly not consistent with Key Immigration Detention Values Four and Five.

Key Immigration Detention Value Seven has clearly been contravened. The effects of Ali, Dawood Jan and Hussain's incarceration led to mental health issues and Ali and Dawood Jan's reluctant acceptance of anti-depressant medication. All also experienced physical health issues. The "inherent dignity" of Ali, Dawood Jan and Hussain, and all of the others similarly detained indefinitely at Curtin IDC and other immigration detention centres, has not been ensured.

\section{Conclusion}

Visiting detention centres means bearing witness to the effects of mandatory detention - the onset of despair, medication, self-harm and suicides. Documenting observations and conversations from these visits can thus help to make visible what is largely hidden from most of the Australian population, as well as form the basis for taking action to stop the abuses. Our observations and the stories we heard provide support for the view that mandatory detention should cease and that detention centres should close, with one of the most urgent closures being Curtin IDC. This mirrors the recent call by Amnesty International Australia that:

\footnotetext{
${ }^{37}$ DIAC, "Key Immigration Detention Values", 2008, available at: www.immi.gov.au/managing-australiasborders/detention/about/key-values.htm (last visited 12 May 2012).
} 
Curtin IDC should be immediately closed for immigration detention purposes. The remote and isolated location of the centre, as well as the extremely hot and dusty physical conditions, greatly exacerbates the existing problems with detaining asylum-seekers. ${ }^{38}$

This paper supports the findings of a growing body of research and media reports that conclude long term detention has harmful consequences for asylum-seekers. Research published over the past few years supports findings of earlier studies that highlight the harmful effects of long term detention during the term of the Howard Government. Rees et al conclude that "there is consistent evidence that prolonged detention, together with harsh conditions in centres, contribute independently to adverse mental health outcomes". ${ }^{39}$ Coffey et al similarly find that "there is enduring harm rendered to asylum-seekers who have been detained for prolonged periods in immigration detention". 40

Recent media reports document similar experiences of self-harm, suicide attempts and suicide in Australia's immigration detention centres under the Labor Government. ${ }^{41}$ A report on Curtin IDC by the Australian Human Rights Commission ${ }^{42}$ raises the same concerns and the Commonwealth Ombudsman ${ }^{43}$ has launched an inquiry into the increasing reports of selfharm and suicide attempts in detention centres. These recent reports suggest that long term detention in Australia's immigration detention centres during the Gillard Government's term in office continues to be harmful to asylum-seekers.

The deterioration in the mental and physical well-being of the men we have witnessed through our visits and email and telephone contact with men at Curtin IDC from January to December 2011, and the interviews with Ali, Dawood Jan and Hussain upon their release from detention, support these findings. Mandatory detention, especially in remote locations such as where Curtin IDC is situated, easily leads to the long-term detention of asylum-

\footnotetext{
${ }^{38}$ AIA, "Detention".

${ }^{39}$ S. Rees, D. Silove, J. Phillips \& Z. Steel, “Asylum-seekers and Psychiatric Injury”, Precedent, Issue 99 , Jul./Aug. 2010, 19.

${ }^{40}$ G.J. Coffey, I. Kaplan, R.C. Sampson \& M. Montagna Tucci, "The Meaning and Mental Health Consequences of Long-term Immigration Detention for People Seeking Asylum", Social Science and Medicine, 70, 2010, 2078.

${ }^{41}$ K. Barlow, "Nurse Breaks Silence on Life inside Detention System" ABC News Lateline, 2 Dec. 2011, available at: http://www.abc.net.au/news/2011-12-01/immigration-nurse-breaks-silence-withincentre/3707620 (last visited 18 May 2012). See also ABC Four Corners, Asylum, 24 October 2011.

42 AHRC, "Immigration".

${ }^{43}$ Commonwealth Ombudsman, "Inquiry to Examine Suicide and Self-harm in Immigration Detention”, 29 Jul. 2011, available at: http://www.ombudsman.gov.au/media-releases/show/189 (last visited 15 October 2011).
} 
seekers, despite the Labor Government's Key Immigration Detention Values that suggest otherwise.

Long-term detention reflects the refugee claims processing suspension in 2010 for Afghans and Sri Lankans as well as the inconsistencies of the processing itself over the past few years. According to DIAC's recent figures, 38 per cent of Afghan asylum-seekers arriving by boat between June 2010 and June 2011 received positive RSA outcomes. However, during the following nine months, 79 per cent of IMR decisions issued resulted in the overturning of negative RSA outcomes. ${ }^{44}$ This highlights that many asylum-seekers had needlessly endured many months of despair in detention waiting for the outcome of their refugee claims.

Recent policy changes adopted by the Gillard Government suggested that efforts were being made to minimise time spent in detention by asylum-seekers. These changes have allowed for many long-term detainees to be released into the community on bridging visas while they wait for their refugee claims to be finalised. However, while this development is encouraging, legislative changes that repeal mandatory detention and ensure minimal time periods of detention for asylum-seekers are needed to ensure that Australian policy is no longer responsible for harming asylum-seekers that come to our shores seeking security. In addition, at the time of writing (August 2012) the Australian Parliament passed legislation allowing for asylum seekers arriving to Australia by boat to be transferred to Nauru and Papua New Guinea's Manus Island. This will allow for asylum seekers who arrive to Australia by boat from 13 August to be transported to one of these islands and held there until their refugee claims are processed and, for those found to be refugees, resettlement places offered. The prospect of long periods in forms of immigration detention in remote locations continues to be Australian policy.

\footnotetext{
${ }^{44}$ Commonwealth of Australia, Proof Committee Hansard, 79.
} 